\title{
The status of governmental relations with reference to decentralisation of public safety and security
}

\author{
EP Ababio and TE TENGENI *
}

\begin{abstract}
Two of the challenges facing South Africa are crime and victimisation. This article explores the effectiveness of governmental bodies in the whole-of-government approach to ensure accountability and oversight over safety and security. Significantly, the article highlights the prevalence of weaknesses in the decentralisation of safety and security powers and responsibilities. Recommendations are offered to help improve and bridge these gaps.
\end{abstract}

Keywords: Governmental relations, safety, security, national, provincial, local government, municipalities, intensity of relations, parliament, legislatures.

Disciplines: Public Management, Political Science, Law, History.

\section{Introduction}

The post-1994 government of South Africa introduced transformative measures in compliance with the constitutional democratic values and principles necessary to, among others, ensure effective and efficient governmental relations and decentralised service delivery. This research article, therefore, explores whether powers, functions, and responsibilities transferred from the national sphere of

* Prof. Ernest Ababio is subject group heads for Public Management and Governance at North-West University's Vanderbijlpark campus. Dr Tamsanqa Edgar Tengeni has a PhD in Public Management and Governance from the North-West University. He has been in municipal management for years as municipal manager, and is currently a Chief Director at Free State Provincial Department of Public Safety, Security and Community Liaison in Bloemfontein. 
government to the provincial and local units and the public are adequate to promote effective, efficient, and equitable safety and security service delivery. Governmental relations as conceptual framework are used to analyse the relations that exist among authorities in national, provincial, and local spheres of government and with communities. The analysis exposes gaps in legislation that reduce efficiency and effectiveness of safety and security service delivery in provincial and local spheres of government. The article therefore makes a contribution to the 'scarce' body of knowledge in governmental relations.

\section{Conceptualisation of governmental relations}

Governmental relations, though not a new concept in public administration, are being tested in practice in democratic South Africa as a result of a relatively complex Constitution of the Republic of South Africa Act (Act 108 of 1996) (hereafter referred to as the 1996 Constitution) that creates spheres of government. Van Niekerk (2002:89) defines governmental relations as “... the regulations controlling orderly relations between individuals in power, government institutions and departments; as well as between governments on various levels with the aim to facilitate co-operation, co-ordination and decision-making".

According to Hattingh (1998:19), governmental relations occurring within the geographic boundaries of a state are classified into three major categories, namely, intergovernmental relations, intragovernmental relations, and extragovernmental relations. Intergovernmental relations refer to the mutual relations between governmental institutions; intragovernmental relations" refer to official relations within an institution; and, as pointed out by Thornhill et al (in Kanyane \& Nazo 2008:139), the concept refers to relations among different governments.. In adition, there is extragovernmental relations which refer to relations between government institutions and members of the public (Hattingh 1998:23-30).

The discussion below focuses on how the decentralisation of powers and responsibilities from national to sub-national units influences governmental accountability and oversight between and among government bodies, on the one hand, and between government bodies and the public, on the other.

\section{Accountability and oversight in safety and security}

The 1996 Constitution establishes that accountability (which, according to Schneider and Moore (2003:13), is the intended outcome of oversight) is one of the core founding values of the democratic system. Margue et al. (1995:164) state that if basic democracy is to be achieved, then the directors of state agencies must be accountable to outside bodies for the running of their departments. 
In their view, accountability includes providing satisfactory answers to questions about the use of funds and the implementation of policies required by the legislature. Public accountability involves what Tengeni (2005:160) calls intra-governmental accountability, a process that is hierarchical and which flows from one who confers responsibility to one who executes it. The agents of accountability from whom authority relationships are derived include: legislators, elected chief executives, the courts and the general public (Kakumba $\&$ Fourie 2007:653) The object of accountability is thus to ensure that the actions by the authority charged with the implementation of policy (such as the police service) are congruent with the values and priorities of the body to which it is accountable. "Accountability" connotes answerability of officials to a designated official or public (Schneider and Moore 2003:14), and "oversight" refers to the monitoring and reviewing of actions of the executive organs of government (Cordner 1999:2).

\subsection{Intergovernmental Accountability and Oversight}

The basis of intergovernmental accountability and oversight in South Africa is the 1996 Constitution, which states that:

- in the Republic, government is constituted as national, provincial, and local spheres of government, which are distinctive, interdependent, and interrelated (section 40(1) of the 1996 Constitution);

- all spheres of government are enjoined to "exercise their powers and perform their functions in a manner that does not encroach on the geographical, functional or institutional integrity of government in another sphere" (section 41(1) of the 1996 Constitution);

- South Africa consists of a single police service (section 199(1) of the 1996 Constitution); and

- the national police service must be "structured to function in the national, provincial and, where appropriate, local spheres of government" (section 205(1) of the 1996 Constitution).

Although there are functional areas of "concurrent" and "exclusive" competence (Schedule A and Schedule B of the 1996 Constitution) among spheres of government, overriding powers of safety and security are reserved for the national sphere of government. For instance, Parliament is empowered to legislate on "any matter", including a list of broad concurrent powers spelled out in Schedule 4 of the 1996 Constitution (section 44(1) of the 1996 Constitution) such as policing to the extent that the provisions of Chapter 11 of the 1996 Constitution confer on the provincial legislatures' legislative competence.

Schedule 5 (of the 1996 Constitution) lists areas of exclusive provincial legislative competence. However, Parliament also has the 
power to legislate in exclusive areas of provincial jurisdiction if it is deemed necessary, for example, to "maintain national security" (section 44(2) of the 1996 Constitution). Lastly, the national executive may intervene when the provincial sphere of government cannot or does not fulfil an executive obligation in terms of the 1996 Constitution or legislation (section 100(1) of the 1996 Constitution).

\subsection{Intragovernmental Accountability and Oversight}

In the national sphere, the hierarchical structure for intragovernmental accountability and oversight consists of Parliament, cabinet ministers, and national government departments; and at the provincial level, it is that of the provincial legislature, executive council, and provincial government departments; while in the local sphere of government, it is the municipal council, mayoral committee/executive and councillors, and municipal departments. Furthermore, the 1996 Constitution merely provides general guidelines for the creation of internal oversight bodies; structures within these bodies are allowed a considerable degree of discretion to establish additional internal bodies (for example, committees) to optimise oversight over safety and security service delivery.

\section{National Sphere of Government}

\section{(a) Parliamentary Portfolio Committees for Safety and Security}

Relations between Parliament and security-related institutions are of vertical intergovernmental. Chapter 4 of the 1996 Constitution states that the National Assembly of Parliament has legislative powers and oversight over the exercise of national executive authority, including the implementation of safety and security legislation. This oversight role is usually manifested through the Parliamentary Portfolio Committees (including the Portfolio Committee on Safety and Security). Portfolio Committees are key mechanisms provided for in the Constitution to assist Parliament in fulfilling its oversight and accountability functions. These committees monitor and review the actions of the different departments of government (including the national and provincial Departments of Safety and Security) and are also charged with holding officials and their ministers accountable (the Minister and Head of Department (HoD) of Safety and Security). The Portfolio Committee for Safety and Security has an oversight role over the executive organ, namely, the MEC, HoD as the administrative head of the Department of Safety and Security, and the Provincial Police Commissioner.

The oversight role of Parliamentary Portfolio Committees is not without challenges. Firstly, the difficulty in monitoring policy against implementation is that policies (or mandates) for which government departments (such as the Department of Safety and Security) are called 
to account may be vague and complex in character and capable of many interpretations. Secondly, Corder et al. (1999:14) state that the South African parliamentary system of government does not give full expression to the notion of separation of powers because of the close relationship between the executive and legislature. The ruling party elects the executive from its leadership and may, therefore, be reluctant to call its leadership to rigorous accounting. Further, in terms of the electoral system of proportional representation, members of Parliament hold and retain their seats on the basis of membership of their political party. Members of the ruling party may, therefore, be reluctant to hold the executive accountable for fear of being perceived as disloyal and risking expulsion.

Thirdly, Portfolio Committee decisions are influenced by partypolitical concerns. Government policy is, of course, ultimately in the hands of ministers and members of Parliament, whose interests usually lie not in the detail of the particular regime (such as the safety and security regime), but with broader questions of public safety. At the broader level, the issues of accountability and oversight are overshadowed by party politics. The Parliamentary Portfolio Committee dominated by one political party may decide to interrogate an issue or not, depending on its party policy.

\section{(b) National (and Provincial) Secretariat for Safety and Security}

The 1995 SAPS Act provides for the establishment of the national and provincial secretariats, chiefly to promote civilian oversight over safety and security service delivery by the police by:

- performing functions necessary or expedient (in view of the Minister/MEC) to ensure civilian oversight of the police;

- promoting democratic accountability and transparency in the police service;

- promoting and facilitating the participation of the SAPS in the government's Reconstruction and Development Programme (RDP);

- monitoring the implementation of ministerial policy (in so far as this may apply to provincial policy, provincial secretariats would be required to monitor police adherence to provincial government policy) and directions by the police service and reporting to the Minister/MEC on this;

- conducting research into any policy matter instructed by the Minister/MEC; and

- evaluating the functioning of the police service and reporting to the Minister/MEC.

Adamolekun (2002:377) states that in order to be effective, a police oversight structure, especially in Africa, must be: 
- independent from presidential, ministerial, and police manipulation. In addition, leaders of the oversight organisation must themselves exhibit the virtues of independence of action, subject to the rule of law, effectiveness and efficiency, fairness, self-restraint, and incorruptibility, especially in relation to the police, government officials, and members of the public;

- adequately and timeously funded;

- in full and constant liaison with appropriate civil society organisations in order to gain their confidence, support, and as a mechanism of voluntary submission to public accountability;

- sufficiently empowered to exercise and perform oversight powers and functions effectively and efficiently. In other words, it should have relatively comprehensive mandates covering police operations, discipline, and conduct as well as legal powers to make it an effective mechanism of reward for good police officers and commanders and dispenser of punishment for bad policemen and women. Furthermore, it should vigorously protect the rights of police officers from abuse by their superiors and commanders and thereby gain the support of the police, including encouraging whistle-blowing;

- sensitive and promptly responsive to complaints; and competent in research, monitoring, and evaluation to determine police performance and conduct.

One of the critical shortcomings of the National and Provincial Secretariats for Safety and Security is their lack of independence. The National/Provincial Secretariat for Safety and Security reports to the Minister/Member of the Executive Council (MEC) for Safety and Security, and such formal reports rarely find their way into the public domain. Furthermore, senior public servants from the national or provincial secretariat are obliged to go through the Minister or MEC as a channel to Parliament or the provincial legislature or its Portfolio Committees for Safety and Security.

\section{(c) Independent Complaints Directorate (ICD)}

Intensity of vertical intergovernmental relations governs in the ICD. The Independent Complaints Directorate (ICD), as a national oversight structure with a presence in all nine provinces, came into operation in April 1997. It is independent from the SAPS and reports directly to the Minister. Section 222 of the 1993 Interim Constitution (Act 200 of 1993) (hereafter referred to as the 1993 Interim Constitution) provided for the establishment of an independent mechanism under civilian control, with the objective of ensuring that complaints in respect of offences and misconduct allegedly committed by members of the SAPS are investigated in an effective and efficient manner. Section 53(2) of the 1995 SAPS Act stipulates that the ICD may, on 
receipt of a complaint, investigate any misconduct or offence allegedly committed by a member, may, where appropriate, refer such investigation to the Commissioner concerned, shall, on receipt of a complaint, investigate any death in police custody or as a result of police action, and may investigate any matter referred to the Directorate by the Minister or MEC.

Extra-governmental relations, that is, interaction between security institutions and the community, are regulated by legislation. Section 18 of the 1998 Domestic Violence Act (Act No. 116 of 1998) (hereafter referred to as the 1998 Domestic Violence Act) stipulates that failure by a member of the SAPS to comply with an obligation imposed in terms of this Act or the National Instructions referred to in subsection (3) constitutes misconduct as contemplated in the 1995 SAPS Act, and the ICD, established in terms of this Act, must forthwith be informed of any such failure reported to the SAPS. Unless the ICD directs otherwise in any specific case, the SAPS must institute disciplinary proceedings against any member who allegedly failed to comply with an obligation. The ICD must, every six months, submit a report to Parliament regarding the number and particulars of matters reported to it in terms of subsection (4)(a) of the 1995 SAPS Act and set out the recommendations made in respect of such matters. The National Commissioner of the SAPS must, every six months, submit a report regarding steps taken as a result of recommendations made by the ICD.

In terms of section 64 of the 1995 SAPS Act and Annexure 5 of the Regulations for Municipal Police Service (MPS), the ICD has been given the same civilian oversight mandate in respect of the MPS as it has in respect of the SAPS. According to Cordner (1999:17), the ICD faces the following oversight challenges and limitation:

- The SAPS is under no obligation to report cases of police misconduct to the ICD. Therefore, that encourages the gross underreporting of cases of police abuse and misconduct.

- The SAPS is not compelled to refer cases of police abuse and misconduct. The ICD relies on cases brought to its attention.

- The ICD only has powers to make recommendations (with the exception of the implementation of the 1998 Domestic Violence Act). It has no powers to compel acceptance or implementation of its recommendations. Furthermore, there is no obligation on the SAPS to give feedback to the ICD in relation to disciplinary action.

- There is no uniform system or proper record-keeping of complaints by stations and, therefore, no comprehensive picture of the extent of police misconduct.

- The relationship and sharing of information between other oversight mechanisms, in particular the Secretariats of Safety and Security, need to be improved. This could be beneficial in terms 
of building the monitoring capacity of oversight mechanisms.

- It has been argued that public knowledge of the ICD remains limited. Furthermore, the provincial offices of the ICD are largely situated in urban centres and, therefore, limit access to the broader public.

\section{Provincial Sphere of Government}

Executive authority in each province vests in the Premier who, together with other members of the Executive Council, is entrusted with implementing all national legislation within the functional areas listed in Schedule 4 (except where the 1996 Constitution or an Act of Parliament provides otherwise). Section 4, Part A, of the 1996 Constitution classifies policing as a functional area of "concurrent national and provincial legislative competence ... to the extent that the provisions of Chapter 11 of the 1996 Constitution confer upon the provincial legislature's legislative competence".

Therefore, each province may approve a constitution or pass legislation regarding a functional area listed in Schedule 4, subject to certain processes and provisions. In effect, this means that a provincial legislature may pass legislation with regard to policing that falls within its competency, provided that this does not conflict with national legislation.

Section 114(2)(a) and (b) of the 1996 Constitution states that a provincial legislature must provide for mechanisms to ensure that all provincial executive organs of state are accountable to it and to oversee the exercise of the provincial executive in the province, including the implementation of legislation, and any provincial organ of State. Furthermore, the provincial legislature or any of its committees (including the Portfolio Committee for Safety and Committee) may summon any person to appear before it to give evidence under oath or affirmation and to produce documents. It may also require any person or provincial institution to report to it and compel any person or institution, in terms of provincial legislation or the rules and orders, to comply with a summons or requirement in terms of paragraph (a) and (b) cited above. In pursuing its oversight functions, the provincial legislature may evoke the extragovernmental relations mechanism. For example, it may receive petitions, representations, or submissions from interested persons or institutions as well (section 115 of the 1996 Constitution).

The relationship between the provincial legislature and the MEC is one of intensity. In addition to requesting the MEC for Safety and Security (as the political head of policing in the province) to answer questions, the legislature also has the power, in terms of section 206(9) of the 1996 Constitution, to require the Provincial Police Commissioner to appear before it or the Portfolio Committee for Safety and Security to answer questions. This links to the obligation of the Provincial Commissioner to "report to the provincial legislature 
annually on policing in the province" (section 207(5) of the 1996 Constitution). Furthermore, the MEC is enjoined to provide legislature with full and regular reports concerning all matters under his/her control. According to section 133 of the 1996 Constitution, the MEC is responsible for carrying out the executive functions assigned to him/her by the Premier, and the former is accountable, both collectively and individually, to the provincial legislature for the exercise of his/her powers and functions. The MEC is also required to act in accordance with the provisions of the national legislative framework, including the 1996 Constitution and the provincial constitution, if one has been passed.

However, the current notion of police accountability and oversight over the South African Police Service is meaningless because the provincial sphere of government (either through the Provincial Portfolio Committee for Safety and Security or the MEC) does not really have direct power and authority over the police service and the delivery of safety and security services in the province. The MEC, for instance, does not have the power to sanction, direct, or reward the police service, as these roles are largely held at national level. Although safety and security oversight functions and responsibilities are devolved by the national to the provincial sphere of government, such mechanisms tend to be fairly subtle, lengthy, limited, or indirect because the control and management of safety and security service delivery are mainly centralised in the national sphere of government. Political authority for the SAPS vests in the Minster of Safety and Security (section 206(1) of the 1996 Constitution), and the National Commissioner of the SAPS (not the MEC) is responsible for the control and management of the entire police service (section 207(1) and (2) of the 1996 Constitution).

\section{Local Sphere of Government}

The 1996 Constitution states that one of the objectives of local government is to promote a safe environment (section 152(1) (d) of the 1996 Constitution). The 1996 Constitution further provides that there must be a "single" police service in South Africa (section 199(1) of the 1996 Constitution) and that the SAPS "must be structured to function in the national, provincial and, where appropriate, local spheres of government" (section 205(1) of the 1996 Constitution). Furthermore, the 1996 Constitution states that national legislation must provide a framework for the establishment, powers, functions, and control of the municipal police service (section 206(7) of the 1996 Constitution).

The 1998 South African Police Service Amendment Act (hereafter referred to as the 1998 SAPS Amendment Act) provided the first piece of such legislation. It prescribes that the national Minister for Safety and Security may make regulations regarding the establishment of municipal and metropolitan police services. Section 64J of the 1998 SAPS Amendment Act provides for a municipal council to establish a 
committee to ensure civilian oversight of the municipal police service. However, a municipal council does not have direct oversight powers over the South African Police Service (SAPS), except through the provincial government. For example, the 1998 SAPS Amendment Act states that the provincial government must monitor that the SAPS, through the office of the Provincial Commissioner, fulfils its responsibilities for scrutiny of, and standard-setting for, municipal policing in the province. Although much of the responsibility for standard-setting and monitoring of the new municipal police agencies is that of the Provincial Police Commissioner, the MEC and the Provincial Secretariat for Safety and Security, through their accountability and oversight functions, will need to ensure that the Provincial Police Commissioner maintains appropriate scrutiny.

\section{Extragovernmental Accountability and Oversight}

Extragovernmental accountability and oversight are constitutionally guaranteed, and they take place through the Community Police Forums (CPFs). The 1993 Interim Constitution made provision for the establishment of Community Police Forums in every police station area and described their role (section 221 of the 1993 Interim Constitution); and the 1995 SAPS Act outlined the objectives of the CPFs.

The CPF is a group of people from the police as well as different sectors and interest groups from the community who meet to discuss crime problems emanating from their communities (Jagwanth 1994:7). CPFs are currently seen as more than a vehicle for civilian oversight in local policing; rather, a trend has developed, within and outside the police service, in which community policing is seen as synonymous with the functions of the CPF. In fact, CPFs remain the most visible expression of community policing in South Africa (Pelser 1999:12). Furthermore, the evaluation of community policing is often done through CPFs.

The political prerogative informing community policing was one of democratic accountability. However, the policy that guides the implementation of community policing in South Africa has, while consistently focusing on the functions of the CPFs, substantially shifted in emphasis. That contributed extensively to the ineffectiveness of CPFs in various localities. For example, the initial emphasis of the CPFs was oversight of the police (as stipulated in the 1993 Interim Constitution). Currently, government policies emphasise liaison, communication, and cooperation (as stated in the 1995 SAPS Act).

\section{Conclusion and recommendations}

The article examined the status of governmental relations with 
reference to decentralisation of public safety and security in South Africa. The following recommendations are, therefore, made with the purpose of prompting government action to address the aforementioned accountability and oversight shortcomings:

- The statutory framework (that is, the 2005 Intergovernmental Relations Framework Act) needs to be amended to accommodate the institutionalisation of horizontal intergovernmental relations between and among the provincial Departments of Community Safety.

- Intergovernmental Safety and Security Sub-committees should be established in the local sphere of government to enhance accountability and oversight in the context of community safety policy.

- Sufficient powers must be delegated to, and significant effort must be mounted to enhance the capacity of, national, provincial, and local safety and security structures of accountability and oversight to enable them to act effectively on their recommendations (for example, Secretariats for Safety and Security, the Independent Complaints Directorate, and Municipal Civilian Oversight Committees).

- Current national and provincial accountability and oversight structures must be afforded sufficient independence, in terms of their reporting lines and basic resources, from the executive (that is, the Minister or Member of the Executive Council for Community Safety).

- The proliferation of accountability and oversight mechanisms and structures, often with unclear and/or overlapping mandates that confuse and retard public participation, must receive immediate government attention.

\section{Bibliography}

Adamolekun, L. 2002. Africa's Evolving Career Civil Service Systems: Three Challenges - State Continuity, Efficiency Service Delivery and Accountability. International Review of Administrative Sciences, Vol. 67, No. 3.

Cordner, G. 1999. Community Policing: Elements \& Effects, in Alpert \& Piguero, Community Policing: Contemporary Readings. Illinois: Waveland Press.

Hattingh, J.J. 1998. Governmental Relations: A South African Perspective. Pretoria: Unisa Press. 
Jagwanth, S. 1994. Defining Community Policing in South Africa. South African Journal of Criminal Justice, 7(2).

Kakumba U and Fourie D.J. 2007. Revitalizing accountability in public management reform: issues and challenges for developing countries. Journal of Public Administration 42:7

Kanyane, M.H. and Nazo L. 2008. Examining South African intergovernmental relations impact on local government: the case of Eastern Cape local government portfolio committee oversight role. Journal of Public Administration 43:3.1

Margue, K.; Vagg, G.; and Morgan, F. 1995. The Political Economy of Democratic Decentralization. Lit Verlag, Hamburg.

Pelser, E. 1999. The Challenges of Community Policing in South Africa. Institute for Security Studies, Occasional Paper No. 42, September.

Republic of South Africa. Regulations for Municipal Police Service. Regulation Gazette 8784; Government Notice No. 1131. Pretoria: Government Press.

Republic of South Africa. Interim Constitution of the Republic of South Africa, 1993 (Act No. 200 of 1993). Pretoria: Government Press.

Republic of South Africa. The South African Police Service Act, 1995 (Act No. 68 of 1995). Pretoria: Government Press.

Republic of South Africa. Constitution of the Republic of South Africa, 1996 (Act No. 108 of 1996). Pretoria: Government Press.

Republic of South Africa. The South African Police Service Amendment Act, 1998 (Act No. 83 of 1997). Pretoria: Government Press.

Republic of South Africa. Domestic Violence Act, 1998 (Act No. 116 of 1998). Pretoria: Government Press.

Schneider, A. and Moore, M. 2003. Measuring Pro-Poorness: Does Decentralisation Help the Poor? ID21 Research Highlight. Accessed at www.id21.org.

Tengeni, P.M. 2005 Promoting accountability as a tool of making government stronger and building partnerships and networks. Journal of Public Adminitration. September.

Van Niekerk, D. 2002. Governmental Relations, in Van der Waldt, G.; Van Niekerk, D.; Doyle, M.; Knipe, A.; and Du Toit, D. 2002. Managing for Results in Government. Johannesburg: Heinemann Publishers. 